\title{
Designing
}

\author{
the future
}

\author{
। \\ ।
}

\section{fables from the}

\section{mobile telecoms}

\section{industry}

Final Version published as

Watts, Laura (2005). Designing the future: fables

from the mobile telecoms industry. Thumb Culture:

the Meaning of Mobile Phones for Society, (eds.)

P. Glotz, S. Bertschi and C. Locke. Piscataway NJ, Transcript Verlag/Transaction.

Laura Watts | I.j.watts@lancaster.ac.uk

Centre for Science Studies

Department of Sociology

Lancaster University

UK 
Figures

\section{Storytelling \\ Sharing \\ Re-experiencing}

Figure 1. These words were copied from a presentation on long-term strategic direction, given at my ethnographic site.

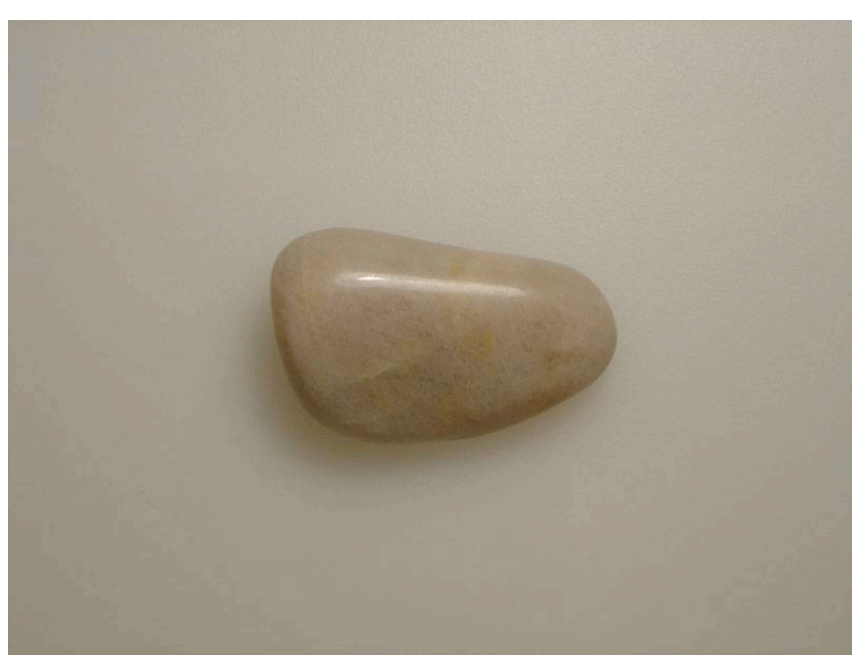

Figure 2. This quartzite stone was collected from inside the glass bowl, sketched below, at my ethnographic site.

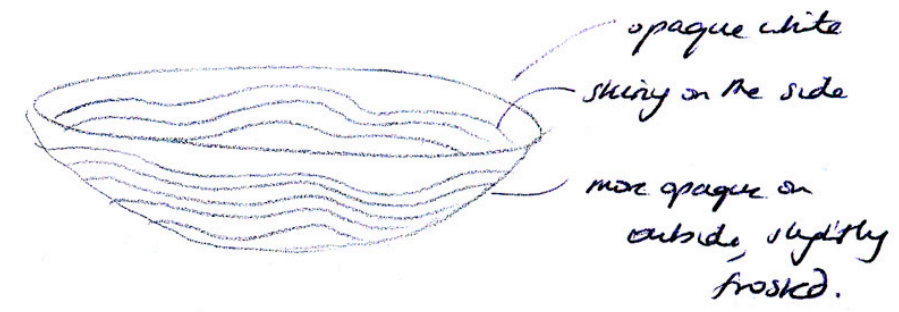

Figure 3. A field sketch of an opaque glass bowl, found on the desk of an industrial designer at my ethnographic site. 


\section{Prologue}

The future: for a manufacturer of mobile devices (phones, camera phones and the rest) the future is a matter of design: What can be made? What will be made? What will sell? The future is made into a product, an artefact. It is designed into being, condensing the multitude of necessary marketing and engineering compromises, negotiated over maybe years of development. But what futures are being made by the industry?

Following are two pieces of writing based upon a four month ethnography at the design studio of a major mobile telecoms handset manufacturer. They also draw on my experiences working as a designer inside the industry during the 1990s. This writing expresses my desire to interfere ${ }^{1}$ with the futures of the mobile telecoms industry - to make differences, rather than to just analyse and critique its practices. Many quotations and artefacts are taken directly from my ethnographic record, however, the events, locations, people and processes have been partly fictionalised ${ }^{2}$, both to protect the anonymity of the company, but also to emphasise that the future is always fluid, transient - there are always many different possibilities. Here, then, are two of them: two possible companies in two very different places, making two possible products and two possible futures. 
Ethnography of 'M-Phone' near London

I sat, thin and exhausted, before a blank burgundy desk divider. The incessant roar of the airconditioning, photocopiers and monitors was steadily draining me away. The line of distant windows, a turquoise sheen against the sky, produced a kind of lifeless illumination that even the overhead spots failed to stir. This was a design studio, and the ambient lighting was eminently well-designed for computer monitors, but I was not alone in longing for the white edge of a brilliant sun - one colour specialist had confided in me that she could only compare colour swatches (and do her job) by leaving the building.

A head appeared above the divider, smiling broadly (yet always with a slight sense of irony). It was Brian, the senior design manager; a man of geometric shirts, cheroots, and tireless enthusiasm; hard to pin down (often either in mid-air, or at least elsewhere in the world) but my indispensable company liaison.

“Ready..?” He asked.

"Absolutely."

Brian had agreed to take me through their future design strategy at eleven (it was now halfpast one). With my ethnographic toolkit in hand, one pencil and a decomposing notebook, I headed with Brian for the meeting room on the far side of the studio.

It was a move from burgundy to magenta. A move from skeletal spines of black cable hanging from the ceiling, into a putrid mass of grey and yellow wires, seething over the table, over the floor, and down the walls. Those network and power cables seemed to fulfil a need to be always oozing into the creature at their centre: the company. A meeting did not mean a flow of shared thoughts or ideas between a group of people, but a queasy pulse of interruptions from other parts of the corporate body. Email set the background pulse rate, with a ceaseless rhythm of mobile phone calls and messages. Most managers emailed constantly, and handling several hundred emails a day was not uncommon (and much lamented).

But this was not a meeting, Brian wandered in without his laptop - he was generously offering his time to pass on what could be passed on of the senior management meetings, held behind closed doors. His mobile phone chirruped. He left. He re-appeared, smiling... His phone rang again... People constantly faded in and out of existence in the studio, as the pulse of the company made them flow around the world.

Finally, Brian put his phone down and stepped up to the projector screen. He began to pound through a hundred or so PowerPoint slides using a touch sensitive board (unfortunately misaligned so that, instead of touching the screen where the button was projected, you had to touch two inches below it).

"Okay, this one's from our consumer research group. Basically, the social trends for technology over the next five years or so are all about Storytelling, Sharing and Re-experiencing". The three words flashed up as a tag-line on a chart filled with a complex blur of graphics (see Figure 1). "That's what it's all about for us. How do we help people tell, share and reexperience their lives?".

He hit (two inches below) the button to go to the next slide. "Physical contexts will continue to blur for consumers" he read, and shrugged. "Pretty self-explanatory, that one." 
Thump. Next slide. "New communities formed." Again, he had nothing to add. He began to pick up pace, blurring the next slides together, stopping periodically at a particular phrase or idea.

It was all fairly standard fare (and no doubt in the blur were more subtle nuances). But, from my own years in the industry, I recognised the moves: the mobile telecoms industry was (still) not in the business of Plain Old Telephony, but in the more refined and wholesome business of building relationships and communities. I was aware, however, of the extensive critiques of cyber-communities, and the potential naiveté of a technologically deterministic argument that suggested mobile telecoms simply made new groups of people. The question of the effect of mobile technology on communities was the rather more subtle question of how groups of people (or diasporas or relationships) might be affected by, and interact with, the technology and also the industry ${ }^{3}$.

We cycled through several more slides, until Brian finally stopped in a flurry of graphics. We were done. My hand ached from writing what I would never be allowed to keep, those slides were too politically sensitive to be given to me. But I had recorded what was regarded as the strategic direction for the company, now the question was: how might that strategy become a device; how might the practice of strategic direction, the presentations and politics, become embedded in a product?

It was time to move on for, as I write this account, I am fusing fragments of my ethnography, the many times and many places, into a narrative; a fable that is accountable only to material and historical fragments, but accountable none the less. The meeting with a senior design manager, is one fragment, a chance conversation with an industrial designer will be another:

As Brian faded into another phone call, I hurried out into the main studio and around the corporate-issue desk pods until I entered the industrial designer's area. As I approached his desk, Andy, the owner, who had been loitering on a sofa in the library, suddenly leaped to my side, friendly (as always) yet faintly suspicious (as always).

We exchanged pleasantries as I scanned his inspirational flotsam: an embossed Japanese drinks can rested on the piles of papers by his monitor, and a small legion of Manga toy figures remained on permanent guard. However, I was particularly taken with a delicate white-frosted glass bowl and the polished quartzite pebbles that rested inside. I took one of the stones into my palm (see Figure 2), and quizzed Andy.

I discovered that he was interested in the texture of the bowl and stones as part of a recent camera phone project. I asked for more, and he wove me this little tale, stroking his black goatee beard as spoke:

"Senior management creates a set of priorities, the strategic requirements for the project: make it big and make it small. So it goes down to middle management, the heads of design and mechanical, who tell us to make it big and make it small. And we scratch our heads and try, and come back to middle management and say: well, we can make it big and make it big, or we can make it small and make it small. Middle management tells senior management, who go: no, we really need it big and small. So middle management say: okay, we'll tell them to try harder. So, we go off and the cycle repeats until senior management shout at us. And then they tell us: oh, but now we want it thin, that's the new priority."

It was a great tale, told with fervour, and I thanked him, although it did leave me with a sense of dislocation; there was no smooth translation between this tale of design practice, and Brian's tale of management strategy. Was there even a translation at all? As I pondered this, Andy asked me if I wanted to see the latest model of the camera phone, which had just arrived. And, of course, I did. 
He pulled open a drawer and extracted a small hard, black case, placing it carefully on the desk top. As the lid was carefully pulled back, it revealed two glistening camera phone models, held tightly in grey foam.

"These were about five thousand each. I think they're almost the most expensive models we've ever had made."

He picked one up, brushed his fingers over the frosted white front. I knew it was made of wood, sprayed to look like metal and plastic, knew from my own design experiences how it would feel slightly warm. Yet it was seductive. I looked back at the white bowl and translucent stones, sensed something of their luminescence in the soft white form of the models. As the quartz pebble in my palm led my fingers to rub, almost absently, at a nagging imperfection, the bevelled edges of the models almost demanded to be touched. But I was cautioned not to handle, or even breath on, their surfaces. The question of touch, of handling, was a serious managerial decision. Focus group testing of new designs with consumers often only involved a plain block model and some illustrations (providing results that were both upheld and quietly derided, depending on the moment). These expensive, fully detailed models were reserved for impressing management and important customers who, I was constantly reminded, were the network operators, not the consumer.

Still fascinated by the models, I quickly sketched the white frosted bowl on Andy's desk (see Figure 3), thanked him again, and moved away; slunk back into my own temporary desk space.

Alone with my notes and sketches, the background noise re-asserted its baleful hum. Of this story, from these fragments of practice at M-Phone, there seemed to be three pieces which together formed a collage: the three words from the corporate strategy 'Storytelling Sharing Re-experiencing' (Figure 1); the frosted white bowl (Figure 3); and the soft quartzite pebble (Figure 2), still held absently in my palm. 
Ethnography of 'Sand 14' on Isles of Orkney

"Oh, hullo there."

I looked up as Anne's bright self, in broad smile and red fleece, crept into the little room. Since arriving in a torrential downpour this morning (before seven - it must have been the long hours of sunlight or possibly the air that had me out of bed so early), I had taken to the odd central hearth to watch the black peat burn amber, and warm my feet over breakfast. I was in the Isles of Orkney, off the North East coast of Scotland, beyond John O'Groats. It was a wild place of broiling seas, wide low skies, and grit. Not a romantic place, treeless and windswept; a place of oil flares, hills and archaeology.

"We'd thought you might have been speared this morning by the rain. Absolute stair rods!"

I grinned. It was impossible not to grin when Anne spoke, her effervescence was infectious.

Sheepishly, I tugged at the ends of my trousers, still slightly sodden. "I think I was only out in it for thirty seconds as I got out of the car, but it just blew under my umbrella."

"Och, umbrellas!" Anne waved her hand at the preposterous notion. "This is Orkney. It rains sideways here, you know. You'll need a riot shield not an umbrella!"

We laughed, as a rows of Orcadians armed with riot shields against the storm, marched through my imagination.

"Richard's suggested we all head off to the mill for coffee, did you want join us?"

Great, a meeting, an opportunity to see how the company functioned in practice. "Yeah, definitely." I scrabbled beneath the wooden seat for my rucksack, its pockets laden with recording devices, ever-ready for an ethnographic moment, and a little reluctantly rose from the fire-warmed chair. It was a tradition at Sand 14 that the fire was always burning, so I threw another peat briquette on the hearth and left the strange little 'house' - holding the smell of peat in my lungs for as long as possible. This little stone building, one-up and one-down, formed the axis of a bright, ultra-modern domed interior - Sand 1 4's premises ${ }^{4}$. Anne and I tracked South, past plants, lights, pin boards, and the other usual and less usual detritus of company life, leaving the dome and corridors of the main work area, to slip quietly into the foyer.

Of course, because this was Sand 14, nothing was quite what I expected. For a design company generating extraordinary (and award-winning) future mobile devices, it was also extraordinarily hard to pin down any formal process, or any methodological approach at all. I was still struggling to see how the art and archaeology expounded by its founders translated, systematically or otherwise, into the concepts and models it produced.

A small group had already gathered in the foyer. Richard, hopping with nervous energy from one foot to the other, and gabbling at high speed to Simon, who was calmly making notes and sketches. George/ina was draped elegantly over the worn black sofa, ignoring all and staring out of the front doors, straight down the path to the towering monoliths in the field beyond. As Anne and I moved into view, however, she leaped to her feet, and with business-like efficiency had us all out of the door, down the path, and inside the company 'bus' (a battered long wheel-base Land Rover with spare parts rolling on the floor) in moments. 
As we drove the wet mile down the road to the café we passed into another world. Sand 14 was inside one of the greatest prehistoric monument complexes in the world; a part of a five thousand year-old architectural project. In the field opposite the grass and slate dome of the company building were three, seven metre high monoliths, once part of a stone circle. As we drove East, we passed the mound of a vast passage grave, a blur of a Neolithic village, a standing stone, and almost in a circle on the far hills all around us, beyond the rain soaked mist, were more standing stones, ever present on the edge of the horizon.

Once we had settled in the old mill café Richard held court as usual, his strange and rather battered satchel overflowing onto the table. He leaned in, almost furtively, over his tea; black eyebrows bouncing up and down as he spoke.

"I have to say, I was a bit surprised at those models", he began, and I rapidly recollected that he had just been to visit a design consultancy in London. "Well, l'd heard about this touchsensitive camera phone, but I rather thought the mock-up I saw looked like a prop from a Nineteen Fifties B-movie."

"It's the whole retro thing." Commented George, sounding slightly bored. "Silver and white, flashing lights, bulbous curve. It's just so totally uninspired. It has no freshness. It's like it doesn't really engage with the world, but is stuck fantasising about styles from the past. I just hate it."

Richard rolled on regardless, fingers weaving the air as though incanting spells. "Well, the day did rather improve, because I wandered into the British Library. I didn't realise, but some of Ingold's recent work on multi-sensory communication talks about the importance of the 'lived experience' as opposed to the reification of the senses 5 . I think this is crucial for us. What we are doing is transforming and translating 6 an experience of the world, not of the individual senses. It's transformation, rather than transmission, which is central. So our work is really how to transform an experience, through silicon and radio, into something else."

"And something no less magical..." murmured Anne.

"Absolutely. Beauty is the key." Agreed Richard.

"But we have been really focused on haptics and force feedback, recently." Simon, the interface designer, looked worried.

"Ah, well, don't worry, this is not a redirection. I think we just need to keep it absolutely clear in our minds that we are not, we are not, designing a multi-sensory communications device, as a kind of evolution of voice and camera phones. That would be quite wrong. We are actually trying to make a rather coarse translation of a bit of the world." He gave a sudden, quick, grin. "I guess it's more like painting."

"I don't think it's anything of the sort, Richard." Said George, piqued.

"Ah, yes." Richard paused for the briefest of moments. "But I do think that we need to be clear that we are not creating a communications device but a shared experience, and I think the two are quite different. I think what we are doing is generative, there's no carrier wave. Nothing is transmitted only transformed."

"Oh, sure." Agreed George. "But it's more like a photograph, which is a very particular, and I think quite bizarre, transformation of the world into a flat rectangle with a single point of perspective7. It is not art. Storytelling maybe, but it's not painting."

The conversation bounced back and forth between the three of them, with the two anthropologists, Anne and I, sharing the quiet space between it all.

Finally George, who seemed, as both artist and businesswoman, to always insist on the salient details, asked Richard how he might pitch this design concept to the mobile telecoms industry. 
Richard winked to the rest of us around the table as he flipped over one of the pieces of paper scattered in front of him. On it, in thick pencil scrawl, were the words: Storytelling, Sharing, Re-experiencing" (see Figure 1).

George read the words, and then laughed. "Brilliant. Yes, they'll love that." She said.

When we returned to the 'house' (no one actually referred to the company premises as an office) I caught up with Simon, eager to understand how this latest move might impact his interface designs. We walked around the arc of flagstone corridor into the central domed atrium - always a blaze of sandstone, spotlights, and glass, with the mist and loch beyond. $\mathrm{He}$ had set up a couple of tables and a floor of paperwork in front of the glass wall; the billowing sky pressing down and around him. I scanned his desk: lots of paper, pens, an old CD player and chewed up headphones; there was one of the white-frosted glass bowls, still full of hot chocolate, the remnants of a French-style breakfast (see Figure 3) - they were always used for drinking chocolate, but I wasn't sure of the significance. There was a laptop, closed and leaning against the window, with a polished quartzite pebble resting on its clasp. I picked it up (see Figure 2), and asked Simon if it was important.

"Feel it." he replied.

I pressed the stone between my thumb and forefinger, rubbed its surface, trying to sense something unexpected. I felt the coldness, the smoothness, but also a slight crease in the surface, a fracture, which drew my thumb.

"You feel the crease?"

I nodded.

"Well that's really want l'm interested in. The imperfection against the smoothness draws your fingers, doesn't it? But it's the colour, the translucency of the polished stone that draws your hand."

"How does that lead to a mobile device?" I asked, alert.

He rummaged on his desk, pulled aside a few constellation maps, and revealed a strange, glistening black object, shaped like a rounded and elegantly sculpted letter ' $T$ '. It was not entirely black, in its depths were pale arteries of white. Nor was it completely smooth, it was etched with some grid pattern at the top. Simon held the maps back, and invited me to grasp the object. The shaft fitted easily down between my fingers and the handle snuggled comfortably into my palm. It was like holding some kind of designer bottle opener. The silken surface felt like sun-warmed marble, heavy, but gorgeous to touch. Instinctively I squeezed it, and felt the give of two pressure pads between my knuckles. A light appeared at one end, projecting down onto the floor. Then, extraordinary waves of what felt like cool water began to lap up and down my fingers. It was delicious. I realised there was a smudge of blue in the light on the carpet, put my other palm into the beam to bring it into focus. It was a picture of someone's hand dangling in lapping water, and I heard a slightly distorted voice from the object whisper: "Can you feel that?"

I could.

I didn't know what to say, almost dropped the device, and gave it back to Simon. "That is ..." I gave up.

Simon grinned. "Isn't it just!" 
Those were two ethnographic accounts. Both accountable to a set of materials, artefacts and words I recorded during my four months of research. Both partly fictional. Neither 'true'. Nor could there ever be a 'true' account, there are only pieces of an archive: dislocated notes and decaying artefacts, all stitched together through a kind of 'poetic archaeology'8. In the words of Marilyn Strathern, there are only ever parts, which are not part of any whole?. All that there is of my four months are my memories (always partial) and my notes (always historical), and a collection of finds (always archaeological). In the space between my experiences of those moments, and the archaeology of my records, there is the possibility for multiple accounts, and multiple 10 stories, to be told. As I followed and recorded a mobile telecoms company, I also made the possibility for other companies. So, the future gets made as a matter of size at M-Phone, and as a matter of experience at Sand 14. The future is made in the mists and monoliths on the Isles of Orkney at Sand 14, and in the pulsing networks and roar of air-conditioning near London at M-Phone. Different places and different practices make different mobile telecoms products - and different mobile telecoms futures.

This article is about stories that are both fixed by the practices of the past, and made fluid by them. It is an excavation into those practices inside the mobile telecoms industry, which make the possibilities for the future, in politics, in design and in products, and in so doing also make other futures, other politics, other designs, and other products. This is, then, is a Future Archaeology. 


\section{Acknowledgements}

Thanks to the many colleagues who have read and commented on this draft, and in particular to Lucy Suchman and John Law. This research was made possible through the support of the Sir Richard Stapley Educational Trust, the Newby Trust and the Kathleen and Margery Elliott Scholarship Trust.

1

\section{References}

Haraway, D. 1991. Simians, cyborgs and women: the reinvention of nature. London: Free Association Books.

Haraway, D. 1997. Modest_witness@second_millennium.FemaleMan ${ }^{\circledR}$ _meets_OncoMouse ${ }^{T M}$. London: Routledge.

Hockney, D. and Joyce, P. 2002. Hockney on 'art': conversations with Paul Joyce. London: Little, Brown.

Ingold, T. 2000. 'Stop, look and listen! Vision, hearing and human movement' in The perception of the environment: essays in livelihood, dwelling and skill. London: Routledge.

Latour, B. 1996. Aramis, or the love of technology. London: Harvard University Press.

Law, J. and Hassard, J. 1999. Actor-network theory and after, Sociological Review Monograph. Oxford: Blackwell.

Miller, D. and Slater, D. 2000. The internet: an ethnographic approach. London: Berg.

Mol, A. 2002. The body multiple: ontology in medical practice. London: Duke University Press.

Richards, C. 1996. 'Monuments as landscape: creating the centre of the world in late Neolithic Orkney'. World Archaeology 28(2): 190-208.

Shanks, M. 1992. Experiencing the past: on the character of archaeology. London: Routledge.

Strathern, M. 1992. Reproducing the future: essays on anthropology, kinship and the new reproductive technologies. Manchester: Manchester University Press. 


\begin{abstract}
1 As a project of 'interference' this writing draws upon the notion of 'diffraction', a generative approach to the mixing of texts and materials, proposed and discussed by Donna Haraway (1991). It is, perhaps, an answer to her question: ""What if the study and crafting of fiction and fact happened explicitly, instead of covertly, in the same room, and in all the rooms?" (Haraway 1997: 110).
\end{abstract}

2 Bruno Latour suggests the genre of 'scientifiction' for such narratives that are partly fictional, partly ethnographic. See his story of the Aramis transport system (Latour 1996).

3 For examples of an anthropological approach to virtual communities see discussions in Miller and Slater 2000.

${ }^{4}$ For more information on the architectural principles involved in the construction of Sand 14 see Richards 1996.

${ }^{5}$ See Ingold 2000.

6 In a Sociology of Translation (also known as Actor-Network Theory) the notion of 'translation' includes the sense that things do not remain unaltered when they move; rather, the practice of changing the relations in which some 'thing' is embedded necessarily changes it. See Law and Hassard 1999.

7 David Hockney (2002) explores this transformation by the photograph in his own artistic practice.

8 See Michael Shanks (1992) for a discussion of 'poetic archaeology'.

9 See Strathern 1992: 90-115.

10 In 'multiple' I am invoking Annemarie Mol's work on 'multiplicity' in medical anthropology. In her example she suggests that, the multiple medical practices involved in arthrosclerosis, produce different versions of the disease; there are "more than one and less than many" arthroscleroses (see Mol 2002). 